\title{
The International Anarchist Archives: A Report on Conditions and a Proposal for Action
}

\begin{abstract}
Andrew Hoyt ${ }^{1}$
Historians spend great amounts of time searching archives for a flake or fragment of the past that will illuminate a story or provide evidence of what someone thought or did. Because historians encounter the past through these collections, the archives themselves hold great sway over how histories are written. In this way, archives influence the narratives which give our lives meaning, impacting how the past is remembered and even how contemporary identities are formed. Yet, archival collections are often found lacking; particularly when it comes to material that informs groups who stood outside the mainstream or elite sectors of society, such as anarchists. Anyone familiar with anarchist groups knows quite well the volume, diversity and creativity of their cultural production. However, due to underfunding and the absence of anarchist produced materials in the majority of state and public archives, very little material created by anarchists has ever been preserved or made available to researchers. This situation limits historians' ability to research anarchist history and thus to fully understand the cultural and historic impact of the anarchist movement; additionally it hinders contemporary radical critique, identity formation, and tactical evolution. [Article copies available for a fee from The Transformative Studies Institute. E-mail address:_journal@transformativestudies.org_Website: http://www.transformativestudies.org (02012 by The Transformative Studies Institute. All rights reserved.]
\end{abstract}

KEYWORDS: Anarchism, History, Archives.

Historians spend great amounts of time searching archives for a flake or fragment of the past that will illuminate a story or provide evidence of what someone thought or did. Because historians encounter the past through these collections, the archives themselves hold great sway over

\footnotetext{
${ }^{1}$ Address correspondence to: Andrew Hoyt, Department of History, University of Minnesota, PO Box 89108 Honolulu, HI 96830; e-mail : a.d.hoyt@hotmail.com.
} 